\title{
COVID-19 ve Epilepsi: Nöbetlere, Tedaviye ve Sosyal Yaşama Etkileri
}

\author{
COVID-19 and Epilepsy: Its Effects on Seizures, \\ Treatment and Social Life
}

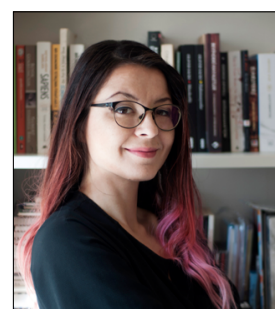

Dr. Ayşe Deniz ELMALI

\section{(i) Ayşe Deniz ELMALI, ${ }^{1}$ (1) Nerses BEBEK, ${ }^{1}$ IIrem YILDIRIM, ${ }^{2}$ (1) Semih AYTA, ${ }^{3}$ (1) Ebru ALTINDAĞ, ${ }^{4}$ (1) Kezban ASLAN, ${ }^{5}$ (1) Sibel K. VELIOĞLU, ${ }^{6}$ (1) Seher Naz YENi ${ }^{7}$}

\author{
IIstanbul Üniversitesi İstanbul Tıp Fakültesi, Nöroloji Anabilim Dalı, İstanbul \\ ${ }^{2}$ Gazi Üniversitesi Tıp Fakültesi, Nöroloji Anabilim Dalı, Ankara \\ ${ }^{3}$ Türkiye Spastik Çocuklar Vakfı, İstanbul \\ ${ }^{4}$ İstanbul Bilim Üniversitesi Tıp Fakültesi, Nöroloji Anabilim Dalı, İstanbul \\ ${ }^{5}$ Çukurova Üniversitesi Tıp Fakültesi, Nöroloji Anabilim Dalı, Adana \\ ${ }^{6}$ Karadeniz Teknik Üniversitesi Tıp Fakültesi, Nöroloji Anabilim Dalı, Trabzon \\ ${ }^{7}$ İstanbul Üniversitesi-Cerrahpaşa, Cerrahpaşa Tıp Fakültesi, Nöroloji Anabilim Dalı, İstanbul
}

\section{Özet}

Koronavirüs hastalığı 2019 (COVID-19) hızla yayılarak her yaşta geniş bir toplum kesitinde görülebilmekte, tüm toplumu olduğu kadar epilepsi hastalarını da etkilemektedir. Virüsün sistemik tutulum dışında nörolojik tutuluma da neden olduğu bilinmektedir. COVID-19 hastalığının mevcut epilepsi nöbetlerini tetiklediği veya kötüleştirdiğine dair bir veri yoktur. Genellikle ikincil olarak nöbetlerin tetiklenebildiği bilinmektedir. Aynı şekilde epilepsili bireylerin COVID-19'a yakalanma olasılıklarının artmadığı ve hastalığı daha ciddi geçirmediği anlaşıımaktadır. COVID-19 için risk oluşturan ek sorunları olmadığı sürece hastaların kullanmakta olduğu antiepileptik ilaçları enfeksiyona yakalanma açısından bir risk oluşturmamaktadır. Hidroksiklorokin, azitromisin ve benzeri COVID-19 tedavisinde kullanılan diğer ilaçların kullanılması gerektiğinde, antiepileptik tedavinin gözden geçirilmesi ve uygun şekilde düzenlenmesi önerilmektedir. Soğuk algınlığı ilaçlarının kullanımı içerdikleri psödoefedrin dolayısıyla nöbet riskini artırabilmeleri, immünomodülatör ilaçlarla enfeksiyon riskinin artması gibi durumlar özel olarak ele alınmalıdır. Bulaşma riskinin en yüksek olduğu yerler hastane birimleri, özellikle de acil birimlerdir. Bu yüzden kişilerin hastaneye ve acile gereksiz başvurmasına yol açabilecek durumları önlemeye yönelik önlemler alınmalıdır. Kişiler salgın döneminde medya araçları, sosyal medya ve web siteleri üzerinden bilgi edinme çabasında olacaklardır. Bu yüzden salgın döneminde sağlık kuruluşlarının ve otoritenin doğru bilgilendirme sağlamaları ve yol göstermeleri büyük önem kazanmaktadır. Bilgilendirmeler hastaların COVID salgınının yaratabileceği riskleri daha doğru görmelerine olanak sağlayacak ve gereksiz yere kaygıya kapılmalarını önlemeye yardımcı olacaktır.

Anahtar sözcükler: COVID-19; epilepsi; önlem; pandemi; SARS-Cov-2; teletıp.

\section{Summary}

Coronavirus disease 2019 (COVID-19) can be spread rapidly and can be seen in a wide section of society at any age, affecting the whole society, as well as patients with epilepsy. A virus may cause neurological involvement, as well as systemic involvement. There is no evidence that COVID-19 disease triggers or worsens existing epileptic seizures. Seizures can be triggered secondary to the disease. Likewise, it is understood that individuals with epilepsy are not more likely to contract COVID-19 disease, and have not had the disease more seriously. Unless there are additional problems that pose a risk for COVID-19, the antiepileptic drugs used by patients do not pose a risk for infection. When it is necessary to use hydroxychloroquine, azithromycin and similar drugs in the treatment of COVID-19, antiepileptic treatment is recommended to be reviewed and properly regulated. Conditions, such as the use of cold medicines can increase the risk of seizures due to the pseudoephedrine they contain, and the risk of infection with immunomodulating drugs should be specially addressed. The risk of contamination is highest in places like hospital units, especially emergency units. Therefore, measures should be taken to prevent situations that may lead to the unnecessary application of people to the hospitals and the emergency units. During the epidemic period, individuals will try to obtain information using media, social media and websites. That is why it is crucial for health institutions and authorities to provide accurate information and guide the people during the epidemic. Informing people will allow patients to see the risks of the COVID epidemic more accurately and help prevent unnecessary anxiety. Key words: COVID-19; epilepsy; prevention; pandemic; SARS-Cov-2; telemedicine.

Geliş (Submitted): 02.07.2020 


\section{Giriş}

Koronavirüs salgını tüm toplumu olduğu kadar epilepsi hastaların da etkileyebilmektedir, kronik bir hastalık olan epilepsiyle yaşamak, bu dönemde bireylerin kaygılarını artırmaktadır. Akut ağır solunum yolu yetersizliği sendromu (SARS) koronavirüsü 2 (SARS CoV-2) ya da daha çok bilinen adıyla koronavirüs hastalığı 2019 (COVID-19) dünya genelinde hızla yayılmıştır ve her yaşta görülebilmektedir. ${ }^{[1,2]}$ Virüsün sadece akciğer veya kalp tutulumu yapmadığı, merkezi sinir sistemi (MSS) ve periferik sinir sistemi de dahil olmak üzere multisistemik bir tutuluma neden olduğu bilinmektedir. ${ }^{[3]}$ COVID-19'un mevcut epilepsi nöbetlerini tetiklediği veya kötüleştirdiğine dair veri yoktur. ${ }^{[4,5]}$ Daha ziyade hastalığın yol açtığı ateş, nefes darlığı gibi sorunların ikincil olarak nöbetleri tetikleyebileceği bilinmektedir. Aynı şekilde epilepsili bireylerin COVID-19'a yakalanma olasılıklarının artmadığı ve hastalığı daha ciddi geçirmediği anlaşılmaktadır. ${ }^{[6]}$ Yüksek risk olarak tanımlanan diyabet, hipertansiyon, kalp hastalığı, immün yetmezlik gibi bir durum epilepsiye eşlik ediyorsa, bu ek hastalıklar nedeniyle riskin artabileceği ve özellikle bu hastalıklar nedeniyle önlemlerini alınması gerektiği barizdir. Bir diğer önemli sorun kullanılan ilaçların etkileşimlerdir. Ancak kullanılmakta olan epilepsi ilaçlarında yapılabilecek değişikliklerin yaratacağı riskler göz önüne alındığında, bu dönemde bu amaçla tedavi değişikliği önerilmemektedir. ${ }^{[6]}$

Salgın döneminde kişiler bilgi edinmek amacıyla birçok kaynağa yönelmektedir. Bunların başında da medya, sosyal medya ve web siteleri gelmektedir. Oysa bu mecralarda bilgi kirliliği olması kaçınılmazdır. Sağlık kuruluşlarının, otoritelerin doğru bilgilendirme ve yol göstermeleri özellikle bu dönemde çok büyük önem kazanmaktadır. Elbette doğru bilgiye ulaşmada en etkin yöntem hastanın kendi hekimine ulaşarak, kendi özelinde bilgilenmesidir. Bu amaçla her sağlık birimi tarafından başlıca takipli hastaların ulaşabileceği bir dijital ortam sağlamak çok kıymetli olacaktır. Bilgilendirmeler hastaların COVID-19 salgınının yaratabileceği riskleri daha net görmelerini, durumu doğru bir biçimde kavramalarını sağlayarak gereksiz kaygıya kapılmalarını önlemeye yardımcı olacaktır.

Bulaşma riskinin en yüksek olduğu yerler hastane birimleri, özellikle de acil birimlerdir. Salgının hasta, hasta yakınları ve sağlıkçılar açısından riskleri göz önüne alındığında hastaların ve yakınlarının hastaneye başvuru ihtiyaçlarının azaltılması riski azaltmak açısından önem taşımaktadır. Ancak ihtiyaç halinde başvuru koşullarının belirlenmesi ve sağlanmasının da COVID-19 enfeksiyonundan bağımsız epilepsiye bağlı gelişebilecek sorunların önlenmesindeki önemi açıktır. Hastaların COVID-19 hakkında ihtiyaç duydukları bilgilere ulaşmaları, epilepsi ve acil durumlarda yapabilecekleri hakkında bilgilendirilmeleri, kafa karışıklıklarını ve gereksiz hastane başvurularını önlemede en önemli yöntemdir. COVID-19 hakkında sağlık otoriteleri ve medya tarafından yapılan yaygın bilgilendirmeler hastaların önlemlerini almalarını ve gereksiz hastane başvurularından kaçınmalarını sağlamıştır. Fakat epilepsinin değişken doğası, soruların çözümünde dinamik bir yaklaşımı gerektirmektedir.

Bu derlemede koronavirüs ve epilepsi nöbetleri ilişkisi, tedavi etkileşimleri, status epileptikus gibi özel durumlar ve hasta bilgilendirme kanallarının güncel bilgiler ışı̆̆ında değerlendirilmesi amaçlanmıştır.

\section{Epilepsi Nöbetleri ve COVID-19 Ilişskisi}

COVID-19 pandemisi sürecinde nörologlar, epileptologlar ve takip ettikleri epilepsi hastalarının zihinlerini en çok meşgul eden sorulardan birisi, epilepsi hastası bireylerin bu yeni koronavirüs enfeksiyonuna (COVID-19) yakalanma risklerinin daha fazla olup olmadığıdır. ${ }^{[7]}$ Epilepsi, nöbetlere neden olan pek çok farklı hastalığı kapsayan bir ana başlıktır, dolayısıyla her bireyin kendi özelinde ele alınması gerekir.

Şu ana kadar elde edilen bilimsel kanıtlara göre epilepsili kişilerin COVID-19'a yakalanma sıklıklarında genel toplumla karşılaştırılıı̆ında bir artış yoktur. Aynı şekilde epilepsi immün sistemi zayıflatan bir hastalık olmadığı gibi, kullanılan antiepileptik ilaçların da koronavirüs enfeksiyonuna yakalanma riskini artırdığına dair bir kanıt da yoktur. Illaçlarla nöbeti olmayan veya çok nadir olan, eşlik eden başka bir hastalığı olmayan epilepsi hastalarında enfeksiyon riskinin artmadığı bildirilmektedir.

Sadece epilepsisi olan bu kişiler, COVID-19'a yakalanma veya şiddetli geçirme açısından epilepsisi olmayanlardan daha fazla risk taşımazlar. Çin, İtalya, ABD gibi pandemiyi yaşamış/yaşamakta olan ülkelerden gelen sınırlı sayıda bilgiler de, ek hastalığı olmayan epilepsi hastalarında riskin artmadığı yönündedir. Benzer şekilde eşlik eden başka sağlık sorunları yoksa epilepsili çocuklar için COVID-19'a yakalanma açısından risk artışı olmadığı belirtilmektedir. İleri yaş, hareket kısıt|ıığı, kronik akciğer hastalığı, diabetes mellitus, hipertansiyon, ağır kalp hastalığı, altta yatan bir nedene bağlı immün fonksiyonlarda bozukluk ve buna yönelik tedavi alıyor olmak COVID-19 açısından yüksek risk anlamına gelmektedir. ${ }^{[8]}$ Epilepsi hastası bu durumlardan birine veya birkaçına sahip ise yeni koronavirüs enfeksiyonu için riski artacaktır. Nöbetlerin kontrol altında olup olmamasından bağımsız biçimde, aşağıdakilere benzer durumlarda epilepsili hastalarda COVID-19 riski artmıştır:

a) Nöbet kontrolü için immün sistemi de etkileyen $\mathrm{ACTH}$, diğer steroidler, everolimus, immünoterapiler gibi ilaçlar kullanan hastalar 
b) İmmüniteyi de etkileyen başka nörolojik ve gelişimsel sorunların varlığı

c) Epilepsinin yanı sıra yutma güçlüğü olan ve akciğerlere sık aspirasyon problemi yaşayan hastalar

Diğer bir açıdan pandemi sürecinde epilepsili hastaların COVID-19'a yakalanırlarsa nöbetlerinde artış olup olmayacağı merak edilen bir başka önemli konudur. Epilepsi hastası özellikle ateşle seyreden bir hastalık geçiriyorsa, nöbetlerde değişiklik veya artış gözlenebilir. Dravet sendromlu hastalar için bu risk daha belirgindir. Bu konuda İspanya'da yapılan ve yaş ortalaması 12.4 yıl olan 277 epilepsi hastasının yakınlarının/bakım verenlerinin doldurduğu yapılandırılmış anket çalışmasında, sadece 15 hastanın (\%5.5) tipik COVID-19 belirtileri gösterdiği, bu hastaların 7'sine SARS-COV2 PCR testinin yapıldığı, pozitif bulunan üçünün genetik kökenli gelişimsel ve epileptik ensefalopatili (GEE) olgular olduğu (Dravet sendromu, STXBP1 ensefalopati, genetik tanısız GEE), üçünün de semptomlarının hafif olduğu, hastaneye yatışlarının gerektirmediği, yine bu olgularda nöbet artışı ve davranışsal kötüleşme görülmediği bildirilmiştir. Aynı çalışmada bakım verenler hastalarda nöbet artışı ve davranışsal kötüleşmeyle birlikte olan faktörleri şöyle sıralamışlardır: hasta yakınlarında yeni başlayan anksiyete ve depresyon belirtileri, teletıp yöntemiyle nöroloğuna ulaşamama, terası/balkonu veya avlusu olmayan bir evde yaşama, ekonomik sorunlar, düzenli uyaran ve fizik tedaviden yoksun kalma, COVID-19 korkusuyla ciddi sağlık sorunlarında hastane acillerine gitmekten kaçınma, gerekli tıbbi randevuların iptal edilmesi ve antiepileptik ilaçların temininde zorluklar. ${ }^{[9]}$

Öte yandan COVID-19'da dahil olmak üzere hastalıklar vücut için fiziksel ve duygusal stres faktörüdür ve nöbete yol açabilirler. Bununla birlikte salgını yaşayan ülkelerden gelen ilk bilgiler, epilepsili hastaların çoğu için COVID-19'la nöbetlerde kötüleşme riskinin düşük olduğunu göstermiştir. Bu yeni koronavirüs enfeksiyonunda ateş için parasetamol (asetaminofen) kullanılması, inflamatuvar yanıtı değiştirdikleri için non-steroid anti-inflamatuvar ilaçlardan -farklı görüşler olmakla birlikte- uzak durulması önerilmektedir. COVID19'un nöbetleri tetikleme olasılığını azaltmak amacıyla epilepsili hastalara ilaçlarını düzenli almaları, doz atlamamaları (salgın sürecinde hayatın normal rutininden çıkıldığı için ilaç zamanlarını hatırlatıcı ek önlemler almaları), ellerinde yedek ilaç bulundurmaları, düzenli beslenmeleri, uyku süresine dikkat etmeleri, COVID-19'a yakalanırlarsa ateş için parasetamol kullanmaları, nöbet artışı yapabilen psödoefedrin ve difenhidraminden kaçınmaları, endişe ve anksiyete için gerekirse teletıp yöntemiyle yardım almaları önerilmelidir.

\section{Status Epileptikus}

Status epileptikus (SE), ciddi nörolojik acil tabloların en sık görülenlerinden biridir. COVID-19'un SE riskini artırdığını gösteren bir veri bulunmamakla birlikte, literatürde nadir olgular bildirilmiştir.

COVID-19 hastalığının neden olduğu sistemik ve/veya nörolojik tutulumun akut semptomatik klinik/subklinik nöbet ve SE gelişimi için bir risk faktörü olabileceği de akla gelmektedir. Bu bağlamda ilk olarak Iran'da sık nöbet ile başvuran, özgeçmiş ve soygeçmişinde epilepsi öyküsü olmayan, 30 yaşında bir kadın hastanın nöbet etiyolojisinde COVID19'un rol oynayabileceği bildirilmiştir. ${ }^{[10]}$ Ancak hastanın beyin manyetik rezonans görüntülemesi (MRG), beyinomurilik sIvIsı (BOS) hücre ve biyokimya değerleri ile BOS'da gerçek-zamanlı polimeraz zincir reaksiyonu (PCR) ile bakılan SARS-CoV-2 incelemesi normal saptanmıştır. Yine de virüsün MSS'ye direkt invazyonu veya salgıladığı toksinler ile ya da beyin dokusundan salgılanan enflamatuvar mediatörler aracılığıyla nöbete yol açmış olabileceği varsayılımıştır. Daha sonra Mao ve ark'nın derlemesinde epileptik nöbet geçiren bir hastadan bahsedilmiş, ancak bu olgunun öncesinde epilepsi hastalığının olup olmadığı veya akut semptomatik nöbet mi geçirdiği rapordan anlaşılamamıştır. Bu derlemedeki hastalara EEG incelemesi ve lomber ponksiyon yapılmamıştır. ${ }^{[8]}$ Nisan 2020'de yayınlanan, COVID-19 enfeksiyonu sirasında akut semptomatik nöbet gelişiminin sıklı̆ı ve risk faktörlerini belirlemeyi hedefleyen çok merkezli, retrospektif bir çalışmada 108'i ağır, 304 hastanede yatan COVID-19 hastasının standart olgu raporları değerlendirilmiş, akut semptomatik nöbet ve/veya SE tablosuna rastlanmadığı bildirilmiştir. ${ }^{[7]}$ Olguların sadece ikisinde izlenen nöbet benzeri semptomlar birinde akut stres reaksiyonu, diğerinde de hipokalsemi ile ilişkilendirilmiştir. Hastaların \%27'sinde akut semptomatik nöbet ve SE için risk faktörü olabilecek hipoksi, hipokalemi, hiponatremi, hipokalsemi, kronik böbrek yetmezliği gibi metabolik bozukluklar, sepsis, septik şok, multiorgan yetmezlik tabloları, imipenem gibi antibiyotik kullanımı, akut inme, travmatik beyin hasarı gibi yapısal beyin lezyonları not edilmiştir. Akut inme sonrası nöbet görülme oranı \%3.1-33 olmakla birlikte bu kohortta akut iskemik inmeli 3 hastada da nöbet izlenmemiştir. Bu çalışmada yazarların kendilerini de eleştirdiği noktalardan biri 8 ensefalopatik hastada nonkonvülzif SE (NKSE) ayırıcı tanıSı için bulaşma riski nedeni ile elektroensefalografi (EEG) incelemesinin yapılmamış olmasıdır. Hastaların klinik bulguları, laboratuvar sonuçları ve tedaviye cevapları dikkate alınarak NKSE olmadıkları sonucuna varılmıştır. Hastaları sadece erken dönemde değerlendiren bu retrospektif çalışmada COVID-19 enfeksiyonunun ve neden olduğu nörolojik ve sistemik bozuklukların erken dönemde akut semptomatik nöbet ve SE gelişimi için bir risk faktörü oluşturmadığı bildirilmiştir. Ancak bu çalışmadaki hastalar da dahil olmak üzere literatürde şimdiye kadar NKSE yönünden değerlendirmesi tam olarak yapılmış hasta bildirilmemiştir. Bu makaleden 3 gün sonra özgeçmişinde hipertansiyon ve 2 yıl önce NKSE ile 
ortaya çıkmış herpes ensefalitine bağlı kontrol altında epilepsisi olan 78 yaşında kadın hasta bildirilmiştir. Sekel afazisi ve hafif sağ hemiparezisi olan hasta COVID-19 hastalığının başka belirtileri olmaksızın fokal motor SE tablosu ile acil polikliniğe getirilmiştir. ${ }^{[1]} \mathrm{EEG}$ incelemesi sol frontosentrotemporal bölgede belirgin, yüksek amplitüdlü, semi-ritmik, delta aktivitesi ile karakterize fokal SE ile uyumlu bulunmuştur. Intravenöz valproik asit ve midazolam tedavisi ile SE tablosunun kontrol altına alındığı not edilmiştir. Beyin MRG'de sol temporo-parietal bölgede geniş bir alanda atrofi ve gliozis izlenmiştir. Acil polikliniğe başvurusundan 12 saat sonra ateşi çıkan hastanın PCR testi pozitif bulunmuş, COVID-19 enfeksiyon tedavisi de başlanmış ve tekrarlayan nöbeti olmamıştır. Akciğer tutulumunun bulgularını göstermeyen bu hastada ne yazık ki virüsün MSS tutulumu da BOS PCR incelemesi yapılmadığı için saptanamamıştır. Her ne kadar semptomların ortaya çıkışı ve kronoloijk sırası atipik olsa da virüsün nörotropik patojenik mekanizma ile nöbetleri tetiklediği ileri sürülmüştür. Nitekim COVID-19 ile yüksek oranda homoloji gösteren SARS ve Ortadoğu solunum sendromuna (MERS) neden olan diğer korona virüslerin MSS'yi doğrudan tutması sonucunda ateşli nöbet, mental durum değişikliği ve ensefalit olguları bildirilmiştir. Hatta daha önceki SARS salgınında jeneralize tonik-klonik nöbetlerle gelen bir hastada BOS'da SARS-CoV PCR pozitif saptanmıştır. SARSCoV-2'nin direkt MSS'ini tutmasının kan dolaşımı veya nöronal retrograd yol aracılı̆ı̆ıla olduğu ileri sürülmektedir. Bunlardan birincisinde kan dolaşımındaki virüs önce kan-beyin bariyerindeki endotel hücreleri veya koroid pleksustaki kanBOS bariyerindeki epitelyal hücreleri enfekte etmekte ya da lökositler aracılığı ile MSS'ye ulaşmaktadır. İkinci yol olarak bazı kranyal (olfaktör sinir, trigeminal sinir, glossofaringeal sinir ve vagus siniri gibi) ya da periferik sinirlerde virüsün retrograd aksonal transportu aracılığıyla MSS'ye ulaşabileceği varsayılmaktadır. ${ }^{[12]}$ Ayrıca koronavirüs enfeksiyonuna artmış immün yanıtın sistemik olumsuz sonuçları (çoklu organ yetmezliği ve/veya dissemine intravasküler koagülasyon ve sepsis) ya da akciğerlerdeki patolojik değişikliklere bağlı gelişen solunum bozukluğu neticesinde dolaylı mekanizmalar ile de nörolojik semptomların ortaya çıkabileceği düşünülmektedir. ${ }^{[1]}$

Nörolog açısından öncelikli hedef SE gelişimini önlemek, mevcut SE hastalarının tanısını hızla koyabilmek, PNES kökenli SE olgularını dışlayabilmek ve SE tanısı konduktan sonra da yoğun bakım ihtiyacını azaltmayı amaçlamak olmalıdır. Yoğun bakım ihtiyacı olan hastalarda ise mümkün olan en kısa sürede hastayı sedasyondan kurtarmak amaçlanmalıdır. Normalde sedasyonun 24-48. saatine kadar beklenirken, özellikle de yatak sıkıntısı çekilen bölgelerde 1-2 antiepileptik ilaç idame dozuna ulaştığında sedasyonun sonlandırılmasının denenmesi düşünülebilir. Böyle olgularda tekrar sedasyon intiyacına karar verirken belirgin elekt- rografik nöbetler veya çok riskli iktal-interiktal paternlerin varlığı aranmalıdır. Dünyanın her yerinde pandemi döneminde yoğun bakım yatakları ve ventilatörler açısından sıkıntı yaşanmakla birlikte, ülkemiz bu açıdan şansı bir konumdadır. Her SE hastasına YBÜ yatağı açısından diğer hastalarla eşit şans tanınmalı, mümkün olan merkezlerde COVID-19 hastası olmayan "temiz" YBÜ'lerde takipleri sağlanmalıdır. ${ }^{[13]}$

Eğer SE, COVID-19 ile komorbid olarak ortaya çıkmışsa, ilaç etkileşimleri çok yakından takip edilmeli, hastaların özellikle EKG monitorizasyonuna önem verilmelidir. Hemodiyaliz veya ekstrakorporeal membran oksijenizasyonu (ECMO) ihtiyacı olan hastalarda antiepileptiklerin de filtreleneceği göz önünde tutularak ilaç kan düzeyleri takip edilmeli, gerekirse ara dozlarla takviye düşünülmelidir.

\section{Tedavi}

Enfekte olmamış epilepsi hastalarında ileri yaş ve benzeri, COVID-19 için risk oluşturan ek sorunları olmadığı sürece kullanmakta olduğu antiepileptik ilaçlar enfeksiyona yakalanmak açısından risk oluşturmamaktadır. Ancak hastalar zaman zaman başvurulmak zorunda kalınan immünsüpresif ilaçlardan herhangi birini kullanmakta ise ya da yeni geçirilmiş bir epilepsi cerrahisi söz konusu ise enfeksiyona yatkınlık artabilir. Bu durumda COVID-19'un genel korunma önlemlerinin çok daha titizlikle uygulanması hastaya ayrıntılı bir biçimde anlatılmalıdır. Yine pandemiye bağIı olağanüstü bir dönemden geçiyor olmanın getireceği stres ve anksiyetenin de nöbet tetikleyici olabileceği unutulmamalıdır. Diğer taraftan hastanın antiepileptik ilaçlara erişim zorluğuna bağlı ilaç alamama gibi nedenlerle nöbet artışları olabileceğinden, ilaç temininin önemi ve ilaçlarını düzenli almaya devam etmesinin önemi hastaya belirtilmelidir.

\section{Anti-COVID tedavilerin epilepsi ve nöbetler üzerine etkileri}

cOVID-19 geçirmekte olan epilepsi hastaları birçok açıdan yakın gözlem gerektirir. Öncelikle COVID-19 tedavisinde kullanılan ilaçlar ile antiepileptiklerin etkileşimi mutlaka göz önünde tutulmalı, tedavinin her basamağında, değiştirilen her ilaçta bu durum mutlaka yeniden gözden geçirilmelidir. Bunun için şu an internette kolayca kullanılabilen araçlar mevcuttur. Bir tanesine şu adresten erişilebilir: https://www. COVID19-druginteractions.org/

Anti-COVID ilaçlar epilepsi üzerine ya direk nöbet tetikleyici etkinlikleri ya da yapabilecekleri sistemik yan etkiler sonucu oluşabilecek komplikasyonlara (karaciğer ve böbrek fonksiyon bozukluğu, elektrolid imbalansı vb) bağlı olarak olumsuz etki gösterebilirler. Nöbet tetikleyici anti-COVID 
ilaçlar arasında nöbet eşiğini düşürebilecek antibiyotikler dikkat çekmektedir. Antibiyotiklerden azitromisin haricindeki çoğu kinolon grubu ve bazı sefalosporin grubu ilaçların kullanılmasından mümkünse kaçınmak gereklidir. Eğer hastalar ileri yaşta, yoğun bakımda ve böbrek fonksiyonları da bozuksa nöbet tetiklemenin yanı sıra bu antibiyotiklerin gerek konvulzif ve gerekse de nonkonvulziv status epileptikusa yol açabileceği unutulmamalıdır. Diğer taraftan antiCOVID ilaçların anti-nöbet ilaçlarla etkileşimine bağlı nöbet artışları olabileceği için, aşağıda detaylandırılacağı şekilde ilaç-ilaç etkileşimleri dikkate alınarak tedaviler düzenlenmelidir (Tablo 1). ${ }^{[14]}$

COVID-19 tedavisinde kullanılan ilaçların nöbet eşiği üzerine etkileri de göz önünde tutulmalıdır. Evde takip edilen olgularda, semptomatik rahatlama amacıyla reçete edilen psödoefedrinler veya antihistaminiklerin hastaların nöbet eşiğini düşürerek nöbet sıklığını artırabileceği hatırda tutul- malıdır. Yatırılarak izlenen olgularda ise özellikle sekonder enfeksiyonların tedavisinde kullanılan sefalosporinlerin ve kinolonların nöbetlere hatta status epileptikusa yol açabileceği düşünülmeli, mümkünse bu hastalarda da nöbet eşiğini değiştirmeyen antibiyotikler tercih edilmelidir.

COVID-19'un özellikle de sitokin fırtınası evresinde multisistemik tutuluma yol açtığı unutulmamalıdır. Karaciğer veya böbrek tutulumu söz konusu olduğunda, antiepileptik ilaçların metabolizması da dramatik bir biçimde etkilenecektir. Bu yüzden de hem toksikasyonlardan, hem beklenmeyen ilaç etkileşimlerinden, hem de yetersiz etkiden kaçınmak için ilaç kan düzeyleri takibi yapılmalı, ilaçlara göre gerekli monitorizasyon önlemleri (örneğin kardiyak monitorizasyon) alınmalı, ilaç dozları karaciğer ve böbrek fonksiyonlarına göre incelikli bir biçimde hesaplanmalıdır. Bu durum hemodiyaliz veya ECMO gibi uygulamalara ihtiyaç duyan hastalarda daha da kritik bir öneme haizdir.

Tablo 1. COVID-19 da kullanılan ilaçlar ile antiepileptiklerin olası etkileşimleri (Son güncelleme 28.06.2020)

\begin{tabular}{|c|c|c|c|c|c|c|c|c|c|}
\hline & ATV & $\mathrm{LPV} / \mathrm{r}^{*}$ & RDV & FAVI & $\mathrm{CLQ}^{*}$ & $\mathrm{HCLQ}^{*}$ & RBV & TCZ & IFN $\beta$ \\
\hline Diazepam & $\uparrow$ & $\uparrow$ & $\leftrightarrow$ & $\leftrightarrow$ & $\leftrightarrow$ & $\leftrightarrow$ & $\leftrightarrow$ & $\leftrightarrow$ & $\leftrightarrow$ \\
\hline Eslikarbazepin & $\Downarrow$ & $\Downarrow$ & $\Downarrow$ & $\leftrightarrow$ & $\Downarrow$ & $\Downarrow$ & $\leftrightarrow$ & $\leftrightarrow$ & $\leftrightarrow$ \\
\hline Etosüksimid & $\uparrow$ & $\uparrow$ & $\leftrightarrow$ & $\leftrightarrow$ & $\leftrightarrow$ & $\leftrightarrow$ & $\leftrightarrow$ & $\leftrightarrow$ & $\leftrightarrow$ \\
\hline Fenitoin $\Downarrow^{* *}$ & $\Downarrow^{* *}$ & $\Downarrow^{* *}$ & $\leftrightarrow$ & $\Downarrow_{* *}^{*}$ & $\Downarrow^{* *}$ & $\leftrightarrow$ & $\downarrow$ & $\leftrightarrow$ & \\
\hline Fenobarbital & $\Downarrow^{* *}$ & $\Downarrow^{* *}$ & $\Downarrow^{* *}$ & $\leftrightarrow$ & $\Downarrow^{* *}$ & $\Downarrow^{* *}$ & $\leftrightarrow$ & $\downarrow$ & $\leftrightarrow$ \\
\hline Gabapentin & $\leftrightarrow$ & $\leftrightarrow$ & $\leftrightarrow$ & $\leftrightarrow$ & $\leftrightarrow$ & $\leftrightarrow$ & $\leftrightarrow$ & $\leftrightarrow$ & $\leftrightarrow$ \\
\hline Karbamazepin & $\uparrow \Downarrow^{* *}$ & $\uparrow \Downarrow^{* *}$ & $\Downarrow^{* *}$ & $\leftrightarrow$ & $\Downarrow^{* *}$ & $\Downarrow^{* *}$ & $\leftrightarrow$ & $\downarrow$ & $\leftrightarrow$ \\
\hline Klonazepam & $\uparrow$ & $\uparrow$ & $\leftrightarrow$ & $\leftrightarrow$ & $\leftrightarrow$ & $\leftrightarrow$ & $\leftrightarrow$ & $\leftrightarrow$ & $\leftrightarrow$ \\
\hline Klobazam & $\uparrow$ & $\uparrow$ & $\leftrightarrow$ & $\leftrightarrow$ & $\leftrightarrow$ & $\leftrightarrow$ & $\leftrightarrow$ & $\leftrightarrow$ & $\leftrightarrow$ \\
\hline Lakozamid & $\leftrightarrow$ & $\leftrightarrow$ & $\leftrightarrow$ & $\leftrightarrow$ & $\leftrightarrow$ & $\leftrightarrow$ & $\leftrightarrow$ & $\leftrightarrow$ & $\leftrightarrow$ \\
\hline Lamotrijin & $\leftrightarrow$ & $\downarrow \% 50$ & $\leftrightarrow$ & $\leftrightarrow$ & $\leftrightarrow$ & $\leftrightarrow$ & $\leftrightarrow$ & $\leftrightarrow$ & $\leftrightarrow$ \\
\hline Levetirasetam & $\leftrightarrow$ & $\leftrightarrow$ & $\leftrightarrow$ & $\leftrightarrow$ & $\leftrightarrow$ & $\leftrightarrow$ & $\leftrightarrow$ & $\leftrightarrow$ & $\leftrightarrow$ \\
\hline Lorazepam & $\leftrightarrow$ & $\leftrightarrow$ & $\leftrightarrow$ & $\leftrightarrow$ & $\leftrightarrow$ & $\leftrightarrow$ & $\leftrightarrow$ & $\leftrightarrow$ & $\leftrightarrow$ \\
\hline Okskarbazepin & $\Downarrow$ & $\Downarrow$ & $\Downarrow$ & $\leftrightarrow$ & $\Downarrow$ & $\Downarrow$ & $\leftrightarrow$ & $\leftrightarrow$ & $\leftrightarrow$ \\
\hline Perampanel & $\uparrow$ & $\uparrow$ & $\leftrightarrow$ & $\leftrightarrow$ & $\leftrightarrow$ & $\leftrightarrow$ & $\leftrightarrow$ & $\leftrightarrow$ & $\leftrightarrow$ \\
\hline Pregabalin & $\leftrightarrow$ & $\leftrightarrow$ & $\leftrightarrow$ & $\leftrightarrow$ & $\leftrightarrow$ & $\leftrightarrow$ & $\leftrightarrow$ & $\leftrightarrow$ & $\leftrightarrow$ \\
\hline Primidon & $\Downarrow^{* *}$ & $\downarrow \Downarrow$ & $\Downarrow * *$ & $\leftrightarrow$ & $\Downarrow^{* *}$ & $\Downarrow^{* *}$ & $\leftrightarrow$ & $\downarrow$ & $\leftrightarrow$ \\
\hline Retigabin & $\leftrightarrow$ & $\leftrightarrow$ & $\leftrightarrow$ & $\leftrightarrow$ & $\leftrightarrow$ & $\leftrightarrow$ & $\leftrightarrow$ & $\leftrightarrow$ & $\leftrightarrow$ \\
\hline Rufinamid & $\Downarrow$ & $\Downarrow$ & $\Downarrow$ & $\leftrightarrow$ & $\Downarrow$ & $\Downarrow$ & $\leftrightarrow$ & $\leftrightarrow$ & $\leftrightarrow$ \\
\hline Sultiam $\uparrow$ & & $\uparrow$ & $\leftrightarrow$ & $\leftrightarrow$ & $\leftrightarrow$ & $\leftrightarrow$ & $\leftrightarrow$ & $\leftrightarrow$ & $\leftrightarrow$ \\
\hline Tiagabin $\uparrow$ & $\uparrow$ & $\leftrightarrow$ & $\leftrightarrow$ & $\leftrightarrow$ & $\leftrightarrow$ & $\leftrightarrow$ & $\leftrightarrow$ & $\leftrightarrow$ & \\
\hline Topiramat & $\leftrightarrow$ & $\leftrightarrow$ & $\leftrightarrow$ & $\leftrightarrow$ & $\leftrightarrow$ & $\leftrightarrow$ & $\leftrightarrow$ & $\leftrightarrow$ & $\leftrightarrow$ \\
\hline Valproat $\leftrightarrow$ & $\Uparrow \% 38$ & $\leftrightarrow$ & $\leftrightarrow$ & $\leftrightarrow$ & $\leftrightarrow$ & $\leftrightarrow$ & $\leftrightarrow$ & $\leftrightarrow$ & \\
\hline Vigabatrin & $\leftrightarrow$ & $\leftrightarrow$ & $\leftrightarrow$ & $\leftrightarrow$ & $\leftrightarrow$ & $\leftrightarrow$ & $\leftrightarrow$ & $\leftrightarrow$ & $\leftrightarrow$ \\
\hline Zonisamid & $\leftrightarrow$ & $\leftrightarrow$ & $\leftrightarrow$ & $\leftrightarrow$ & $\leftrightarrow$ & $\leftrightarrow$ & $\leftrightarrow$ & $\leftrightarrow$ & $\leftrightarrow$ \\
\hline
\end{tabular}

Anlamlı etki yok: $\leftrightarrow$, COVID ilacında azalma: $\Downarrow$, COVID ilacında artma: $\Uparrow$, AEl azalma: $\downarrow$, AEl artma: $\uparrow$, birlikte kullanılması sakıncalı ilaçlar: **, ilaçlardan biri veya ikisi QT veya PR uzaması yapar: *.

Kırmızı: birlikte kullanımdan kaçınılmalı, turuncu: yakın izlem gerekir, sarı: minör etkileşim, renk yok: anlamlı etkileşim olmadığı düşünülür. ATV: Atazanavir; LPV/r: Lopinavir/ritonavir; RDV: Remdesivir; FAVI: Favipiravir; CLQ: Klorokin; HCLQ: Hidroksiklorokin; RBV: Ribavirin; TCZ: Tocilizumab; IFN- $\beta$ : İnterferon beta. 


\section{Anti-nöbet tedavilerin COVID-19 enfeksiyonuna etkisi}

Klasik antiepileptik ilaçların COVID-19 riskini artırdığını gösteren herhangi bir kanıt bulunmamaktadır. Dolayısıyla hastaların mevcut tedavilerini aynı şekilde sürdürmeleri, AEI rejiminde değişiklik yapılması gereken hastalarda ise her zamanki kılavuzlara uygun şekilde tedavinin düzenlenmesi uygundur.

Anti-nöbet tedavi, anti-COVID ilaçlar üzerinden veya COVID-19 enfeksiyonunun semptomları üzerine etkili olarak enfeksiyonun seyrini etkileyebilir. Antiepileptik ilaçların enfeksiyon riskini veya hastalığa bağlı ciddi komplikasyon riskini artırdığına dair bir kanıt olmamakla birlikte everolimus veya steroidler gibi immünsüpresyon yapan antiepileptik olmayan antnöbet tedavilerin ve solunum depresyonu yapan benzodiyazepinlerin kullanımının COVID enfeksiyonu tedavisini olumsuz yönde etkileyebileceği göz önünde bulundurulmalıdır. Diğer taraftan antiepileptik ilaçların bir kısmı anti-COVID ilaçların kan ilaç düzeylerini düşürerek tedavi etkinliğinin azalmasına yol açabilirler (Bakınız: ilaç etkileşimi alt başlığı) (Tablo 1). Karbamazepin, fenitoin, pirimidon ve fenobarbital gibi konvansiyonel antiepileptiklerin çoğu karaciğer enzim sistemini indükleyerek anti-COVID ilaçlarla ciddi etkileşim gösterip onların etkinliğini azaltabildiklerinden birlikte kullanımları önerilmemektedir. ${ }^{[15]}$

Ancak immün kökenli epilepsilerde kullanılan immünsüpresif tedaviler veya özel hasta gruplarında kullanılan kemoterapötikler gibi ilaçların enfeksiyon açısından belirgin bir risk yaratabileceği açıktır. Bu gruptaki hastalardan, tedavisinin ertelenmesi, tedaviye ara verilmesi veya başka bir tedavi ajanıyla değiştirilmesi mümkün olanlarda bu ihtimal hasta ve yakınlarıyla da konuşularak değerlendirilmelidir. Bunun mümkün olmadığı ve tedavinin mutlaka sürdürülmesi gereken olgularda, hasta ve yakınları daha sıkı hijyen ve izolasyon önlemleri konusunda uyarılmalıdır. Eğer mümkünse hasta ve bakım veren kişilerden en az birinin evde birlikte izolasyona alınması önerilmelidir.

\section{Anti-nöbet ilaçlar ve anti-COVID-19 ilaçların etkileşimi}

Bugün için COVID-19 pandemisinde enfekte olan hastalar, yıllardır kullanılmakta olan bazı ilaçlarla tedavi görmektedirler. Favipiravir (FAVI), remdesivir, umifenovir ve lopinavir/ritonavir gibi çeşitli antiviral ilaçlar, azitromisin gibi antiinflamatuvar özelliği olan antibiyotikler ve klorokinin ve hidroksiklorokinin gibi antimalaryal ilaçların COVID-19'daki potansiyel etkinlikleri göz önüne alınarak tek başlarına veya kombine olarak kullanılmaktadırlar. Bu bağlamda bu ilaçlarla, anti-nöbet etkili ilaçların (antiepileptik ilaçlar (AEi) ve otoimmuniteye etkili ilaçlar (steroidler, tocilizumab, everolimus, İnterferon beta gibi) etkileşimleri gündeme gelmektedir Eğer bir epilepsi hastası COVID-19 enfeksiyonu geçirmekte ise tabloyu yönetmek zorunda kalan hekimlerin kombine kullanımda doğabilecek ciddi sorunlar açısından hem antiepileptikleri hem de anti-COVID ilaçları tanımaları ve etkileşimlerini bilmeleri gereklidir. ${ }^{[16]}$ COVID-19 tedavisinde kullanılan güncel ilaçlarla AEI'lerin etkileşimine dair veriler sınırlıdır. İngiltere Liverpool Üniversitesi Liverpool İlaç Etkileşimi Grubunun, İsveç Basel Üniversite Hastanesi ve Hollanda Radboud UMC ile birlikte hazırladıkları ve 9 Nisan 2010 de güncelledikleri rehbere göre bazı AEl'lerin güncel anti-COVID ilaçlarla etkileşme riski vardır (Tablo 1). ${ }^{[14]}$ Tedavi süresinde etkileşimi olabilecek ilaçlar için doz ayarlaması veya sıkı takip yapılmalıdır. Epilepsi tedavisinde kullanılan AEl'lerden özellikle birinci jenerasyon karbamazepin, fenitoin, pirimidon ve fenobarbital gibi konvansiyonel AEi'lerin çoğunluğu karaciğer sitokrom P450 enzim sistemi üzerine etkili ilaçlar olup, ilaç-ilaç etkileşim potansiyeli yüksektir, etkinliğini azaltabildiklerinden birlikte kullanımları önerilmemektedir. Eğer karbamazepin (KBZ) veya fenitoin gibi sitokrom CYP3A4 indükleyen ilaçlar kullanılması gerekli ise, kan ilaç düzeyleri yakın takip edilmek koşulu ile kontrollü kullanılabilir. Karbamazepin almakta olan epilepsi hastalarında antiviral ajanların kan ilaç düzeyleri düşerken, antienflamatuvar etkisi de olan azitromisin haricindeki diğer antimikrobiyal ilaçların (klaritromisin, eritromisin, telitromisin), CYP3A4 enzim inhibisyonu etkisi sonucu da karbamazepinin ilaç düzeyi kanda artıp entoksikasyona yol açabileceği bilinmelidir. Bu durumda mevcut dozajın \%3050 azaltılması uygun olacaktır. Hastalar olası toksik bulgular (bulantı, kusma, dizziness, uykululuk, baş ağrısı, çift görme ve konfüzyon gibi) açısından dikkatle gözlenmelidirler. Ritonavir, CYP3A4'ü inhibe ederek KBZ'nin toksik dozlara çıkmasına yol açabilir veya UGT1A4'ü indükleyerek lamotrijinin metabolizmasını hızlandırıp etkinliğini düşürebilir. Bir diğer önemli etkileşimlerden birisi kardiyak yan etkilere sahip ilaçları birlikte kullanımında ortaya çıkabilir (Tablo 1). Klorokinin veya hidroksiklorokinin, azitromisin ve atazanavir QT uzaması ile giden taşi-aritmi yapıcı etkileri olan ilaçlar listesindedirler. Bu bağlamda kardiyak aritmi ve/veya QT uzaması yapan AEl'ler ile birlikte kullanımları dikkat istemektedir. Antiviral ilaçlardan lopinavir/ritonavir ve antiepileptik ilaçlardan karbamazepin fenitoin, lakozamid ve eslikarbazepin uzamış PR aralığına yol açan ilaçlardandır. Her iki grubun da acil durumlarında endikasyonu olan propofolün de relatif olarak disritmi potansiyeli olan ilaçlar arasında olduğu hatırda tutularak dikkatle kullanılması gereklidir. Kardiyak disritmi yapıcı antiCOVID ve anti-nöbet medikasyonların birlikte kullanımları gerekiyorsa, hastaların tedavi öncesi ve esnasında EKG ile takipleri gerekir (Tablo 1). ${ }^{[17]}$ Antiviral ilaçlar ile ilaç etkileşim riskinin az olduğu bilinen AEller arasında ise gabapentin, lakozamid, levetirasetam, pregabalin, topiramat, zonizamid, retigabin ve vigabatrin vardır (Tablo 1). Antiviral ilaçlar arasında ise ribavirin ve FAVI'nın AEl'ler ile anlamlı bir etkileşiminin olmaması tercih nedeni olabileceklerini göstermektedir. Diğer taraftan lamotrijin kullanmakta olan bir epilepsi hastasında, lopinavir/ritonavir (LPV/r) başlanması gerekirse 
lamotrijinin kan ilaç düzeyinin \%50 oranında azalabileceği bilinmelidir, lamotrijin dozunun bu süre boyunca artırılması gerekebilir. LPV/r ise valproik asitle birlikte kullanıldığında iyi yönlü etkileşim olduğu bilinmektedir. Valproik asit karaciğer sitokrom P450 enzim sistemini inhibe ettiğinden dolayı LPV/r'nin düzeyinde $\% 38$ oranında artışa sebep olacaktır. ${ }^{[18]}$ Sadece bir olgu bildirimine ise LPV/r'nin valproik asit ilaç düzeyini \%48 oranında azaltabileceği bildirilmiştir. Bu etkileşim bilgisinin, manisi olan ve valproik asit kullanan bir hastanın LPV/r kullanımı sonrasında mani tablosunun artması sonucu saptandığı görülmektedir. Azitromisinin yanı sıra seçilebilecek diğer antimikrobiyal ilaçlardan makrolid, kinolon grubu ve bazı ikinci üçüncü jenerasyon sefalosporinler gibi antibiyotiklerin kullanımı gerektiğinde bunların nöbet tetikleyici etkileri göz önünde bulundurulmalıdır.

\section{Laboratuvar İncelemeleri}

COVID-19 pandemisi hastalarımızı etkileyebileceği gibi, hasta ile temas eden sağlık çalışanlarını da farklı yönleri ile etkilemekte ve bu durum önümüzdeki dönemde karşılıkı olması kaçınılmaz gibi görünmektedir. ${ }^{[19]}$ Pandeminin doğası gereği, hastalık kontrol edilene kadar incelemeyi yapacak ve inceleme yapılacak olanların karşılıklı bulaşı önleyici nitelikte koruyucu önlemler alması önemlidir. COVID-19 solunum yolu enfeksiyonu olarak tanımlanmakla birlikte hasta takibi sırasında nörolojik semptomların geliştiği bilinmektedir ve bu hastaların bir bölümüne EEG kaydı gerekeceği aşikardır. Bununla birlikte farklı tanılar ile kliniklerde yatmakta olan hastalar dahil olmak üzere, poliklinik takipleri bulunan hastalara da inceleme gerekecektir. Pandemi süresince acil olmadıkça rutin değerlendirme amaçlı EEG çekilmemesi önerilmektedir. EEG laboratuvarlarında, EEG çekimi ve yoğun bakımda ya da serviste video EEG monitorizasyon konvülzif paroksismal olayların, konvülzif ve non-konvülzif status epileptikusun belirlenmesi ve değerlendirilmesi, beyin iskemisinin saptanması, derin sedasyonun monitorizasyonu, ensefalopati ve ensefalitlerin irdelenmesi, koma tablosunda olan hastaların prognozlarının belirlenmesi, beyin ölümünün değerlendirilmesi amacı ile kullanılmalıdır. EEG çekimi için laboratuvarlarda aşağıda sayılan temel parametrelerin çözümlenmiş olması gerekmektedir. ${ }^{[20,21]}$

Uygun laboratuvar koşullarının sağlanması hususunda için mevcut klavuzun izlenmesi uygun olacaktır. ${ }^{[22]} \mathrm{https}: / / \mathrm{www}$. noroloji.org.tr/haber/748/pandemi-surecinde-emg-veeeglaboratuvarlari-icin-oneriler.

Kısa vadede tedavi kararını değiştirecek laboratuvar tetkikleri gerçekleştirilmelidir. Özellikle EEG ve kranyal görüntülemelerde, mümkün ise kısıtlı bir ekip ve az sayıda randevu prensibiyle çalışılmalıdır. Örneğin bir dönem boyunca hep aynı teknisyenin çekimleri gerçekleştirmesi ve tetkiklerin "günün nöroloğu" olarak atanan bir hekim tarafından de- ğerlendirilmesi hem sağlık personelinin maruziyet riskini azaltacak, hem de olası vakalar söz konusu olduğunda filyasyon kolaylığı sağlayacaktır. ${ }^{[23]}$

Özellikle status epileptikus ön tanılı, ajite olan, sekresyonları olan hastalarda, her hastaya COVID-19 olgusuymuş gibi yaklaşılmalı, damlacık oluşturan işlem gibi önlemler alınmalı ve kişisel koruyucu ekipman kullanılmalıdır.

\section{Pandemi Sırasında Epilepsi Hastaları için Hekimlerin Yapabilecekleri}

Bilindiği üzere, COVID-19 pandemisi, tüm dünyada olduğu gibi ülkemizde de hayatı ciddi derecede etkilemektedir. Toplumun her kesiminde önemli değişimlere neden olduğunu, hatta bu değişimlerin uzun vadede kalıı etkilerini göreceğimizi söyleyebiliriz.

Salgının kontrol edilmesine yönelik alınan önlemler ile beraber eğitim-öğretim yöntemleri, çalışma şekilleri, üretici tüketici zinciri ve gündelik yaşam koşulları büyük bir hızla değişmektedir. Zaten zorlu bir kronik hastalıkla mücadele eden epilepsi hastalarımıza üzerine eklenen pandemiye yönelik tıbbı önerilerin yanı sıra, bu süreçte yardımcı olacak genel önerileri şu başlıklar altında inceleyebiliriz.

- Genel sağlıklı yaşam önerileri (egzersiz, sağlıklı beslenme ve hidrasyon, uyku hijyeni).

- Günlük rutinin korunması, zihinsel sağlık (hobilere vakit ayırma, salgın ile haberlerin aşırı takibinden kaçınma, sosyal iletişim).

- Hastane başvurularından kaçınılması, acil durumlarda çözümler.

- Düzenli ilaç kullanımı için motivasyon, tetikleyicilerden kaçınma.

Epilepsi hastalarımıza önerilerimizin başında tabi ki salgından korunma ve sağlıklı yaşam önerileri olacaktır.

Hastalarımıza COVID enfeksiyonu bulaşma riskinin en yüksek olduğu yerler hastanelerdir. Bu nedenle hastane başvurularının en aza indirilmesi riskin azaltılmasında en önemli basamaktır. Ancak acil ihtiyaç durumlarında başvuru yapılması gerekmektedir. Virüsün esas olarak kişiden kişiye yayıldığı düşünülmektedir. Son zamanlarda yapılan çalışmalar COVID-19'un semptom göstermeyen kişiler tarafından da yayılabildiğini gösterdiğinden mümkün olduğunca sosyal mesafenin korunması ve sosyal izolasyon kurallarına uyulması önem taşımaktadır.

Bu süre zarfında mental sağlık ve psikososyal refah, fiziksel durumu yönetmek kadar önemlidir. Tüm toplumda, sağıklı bireylerde dahi travma yaratan bu sürecin kronik bir hasta- 
Iığı olan bireyleri daha derinden etkilemesi kaçınılmazdır. Zaten epilepsinin doğası gereği hayatlarında endişe ve bilinmezliğin büyük bir rol oynadığı epilepsi hastalarının bu salgınla ilgili yaşadıkları psikososyal sıkıntının, Japonya'da Fukushima faciası nedeniyle bölgeden tahliye edilen kişilerle benzer düzeylerde olduğunu bildiren çalışmalar mevcuttur. ${ }^{[24]}$ Bu stres düzeylerinin özellikle dirençli epilepsi hastalarında ve medyadan salgınla ilgili haberleri takip eden kişilerde daha yüksek olduğu gösterilmiştir. Bu dönem de artan psikolojik sorunların temelinde hasta olma endişesi, stres ve sosyal izolasyonun getirdiği yalnızık duygusu yatmaktadır. Günlük rutinlerin değişmesi, boşluk hissi ve ne zaman sonlanacağının bilinmemesinin verdiği belirsizlik bu sürecin uzamasına ve depresyona neden olabilmektedir. Ayrıca sık karşılaşılan diğer bir problem temizlik ve sterilizasyon işlemlerinin aşırı artarak obsesif kompülsif bozukluğa kadar ilerleyebilmesidir.

\section{Sağlıkı Veri Akışı ve Bilgilendirmenin Sağlanması}

Bu sorunların birçok insanın yaşadığı ortak problemler olduğu ve epilepsi hastalığı ile ilgili bir risk artışına yol açmamasının bilinmesi kaygılarının azalmasını sağlayacaktır. Stres arttıran sosyal medyada dolaşan bilgi kirliliği nedeniyle sadece bilimsel verilere güvenmek gerekmektedir. Bu nedenle Türk Epilepsi ile Savaş Derneği web sayfasındaki güncellenen hastalara yönelik verileri takip etmeleri yeterli olacaktır. Salgınla ilgili alınabilecek genel önlemlerin yanı sıra, hastalıklarının bu salgından nasıl etkileneceği, tedavilerini nasıl sürdürecekleri, acil durumlarda nasıl hareket etmeleri gerektiği gibi konular yalın bir dil ile hastalara anlatılmalıdır.

Bu aşamada stres yönetimi için yararlı kişisel alternatifler geliştirmek gerekmektedir. Bunlar arasında sağlıklı beslenmek, kitap okumak, ev içi fiziksel aktivite, hobi ve diğer uğraşılar, aile ve arkadaşlar ile dijital olarak temas halinde kalmak sayılabilir. Bu önlemler sonrası devam eden problemler mevcutsa öncelikle online görüşme yapılan psikolojik destek programlarına, teletıp randevu sistemi üzerinden ulaşııması önerilebilir.

\section{Nöbet Riskini Azaltacak Önlemler}

Bu dönemde atılması gereken en önemli adımlardan biri nöbet riskinin azaltılmasına yönelik alınacak önlemlerdir. Nöbet sıklı̆ının azalması hem hastaların ve yakınlarının anksiyetesine faydalı olacak, hem de hastane başvurularının sıklığını azaltarak SARS-COV-2 maruziyeti ihtimalini en aza indirecektir.

Bu amaçla ilk hedef hastalara düzenli ilaç tedariğinin sağlanmasıdır. ${ }^{[6,12]}$ Düzenli antiepileptik ilaç kullanımındaki aksamalar 2003 yılındaki SARS salgını sırasında karşılaşılan önemli sorunlardan olmuştur. ${ }^{[25]}$ Bunun için hekimlerin ve sağlık bakanlığı, sosyal sigortalar kurumu gibi kurumların birlikte hareket etmeleri gerekir. Hali hazırda ülkemizde uygulanan ilaç kullanım raporlarının süresinin uzatılması ve reçetesiz olarak eczaneden ilaç temin edilebilmesi, birçok hastanın gereksiz yere hastaneye başvurmasının önüne geçmekte çok faydalı olmuştur. Bunun yanı sıra, yeni düzenlenen ilaç raporlarında ve reçetelerde de, hekimlerin tedavinin uzun vadede değişimini de göz önüne alarak düzenlemeler yapmaları (örneğin uzun vadede doz artırımı planlanıyorsa ilaç raporlarının buna uygun olarak düzenlenmesi) ve daha uzun süre yeterli olacak şekilde ilaçları reçete etmeleri mantıklı önlemler olabilir.

Bu dönemde nöbetsiz olan hastalarda ilaç doz azaltımı veya kesimi kararlarının ertelenmesi uygun olacaktır. Kırmızı bayraklara rağmen ilaç kesimi denenen olgularda (örneğin kısa süredir nöbetsiz, EEG bulguları aktif ancak gebelik talebi nedeniyle ilaç kesilmesi düşünülmüş olgular gibi), hasta ile ayrıntılı yarar-zarar analizi yapılması ve gereken olgularda eski doza dönülmesi uygun olabilir. ${ }^{[6]}$

Seçilmiş hastalarda kullanılan benzodiazepin grubu kurtarıcı ilaçların reçete edilmesi konusunda bu dönemde eşik düşük tutulmalıdır. Özellikle de nöbetleri kümelenme özelliği gösteren ve bu yüzden acil başvurusu ihtiyacı olan hastalarda, bakım veren kişinin kooperasyonu ve eğitimi sağlanabiliyorsa bukkal midazolam gibi kurtarıı ilaçların reçetelenmesi hastaların hastaneye başvuru ihtiyacını azaltabilir.

\section{Hasta Takip ve Tedavisi}

\section{Teletip}

Teletıp hasta ile hekimin uzaktan haberleşmesini veya hekimin hastaya ait tetkik sonuçlarına, görüntülemelerine ulaşarak başka hekimlere uzaktan konsültasyon hizmeti sunmasını sağlayan sistemleri tanımlamak için kullanılan bir şemsiye terimdir ve günümüzde giderek popülerliği artmaktadır. Özellikle salgın döneminde, hastaların hastaneye gelme ihtiyacını büyük ölçüde ortadan kaldırması nedeniyle bazı ülkelerde yoğun bir biçimde tercih edilir hale gelmiştir. Özellikle Amerika'da, salgının da etkisiyle hızlıca yasal düzenlemeler yapılarak ve geri ödeme yapılandırmaları gerçekleştirilerek rutin olarak kullanılır hale gelmiştir. Avrupa'da da ülke bazında değişiklikler olmakla birlikte, uygulanabildiği yerlerde gerekli muayenelerin teletıp üzerinden gerçekleştirilmesini yüreklendiren öneriler sunulduğu göze çarpmaktadır. ${ }^{[0,26]}$

Teletıp uygulamaları senkron ve asenkron olmak üzere ikiye ayrııı. Görüntülü veya telefon aracılığı ile gerçekleştirilebilir. İdeal olanı hastayla hekimin birbirini görmesini sağlayan yüksek çözünürlüklü video-ses sistemleri aracılı̆ı̆ı ile senkron (gerçek zamanlı olarak) gerçekleştirilmesidir. Hastanın 
gerçekten de beyan ettiği kişi olduğunu doğrulamak için iki faktörlü doğrulama yapılması önerilmektedir. Ardından tıpkı ofiste yüz yüze görüşmede olduğu gibi kişiden ve yakınlarından anamnez alınır. Vital bulguların ölçümü, fundoskopik inceleme, reflekslerin muayenesi ve vestibüler testler teletıp aracılığı ile gerçekleştirilemeyecek olsa da, nörolojik muayenenin büyük bir kısmı, iyi koopere bir hastada gerçekleştirilebilir. Örneğin, kas gücü hakkında ayrıntılı parezi testleri (Örn; mingazzini, grasset-gaussel testleri gibi) fikir sahibi olmak mümkün olabilir. Epilepsi hastaları bu konuda görece avantajlı bir konumdadır. Zira hastalığa dair en kıymetli veriler genellikle anamnezden veya evde çekilen video kayıtlarından elde edilmektedir ki bunların teletıp aracılığı ile hekime aktarılması oldukça kolaydır.

Ancak henüz ülkemizde yasal dayanağı mevcut olmadığı için, teletıp üzerinden hasta muayenesinin gerçekleştirilmesi, tedavisinin başlanması veya takiplerinin sürdürülmesi mümkün değildir. Kişisel verileri koruma kanunu açısından da yeri tanımlanmamış olan bu yöntemle şu an için tanı koymak veya tedavi başlayabilmek mümkün değildir. Her ne kadar adli tıp bakış açısıyla hastayı korumak için mantıkı bir yöntem olarak öne çıksa da, "normal" muayenenin bir alternatifi gibi algılanmamalıdır. Mevcut koşullar altında ülkemizde hekimin hastasına teletıp aracılığı ile ancak danışmanlık ve yönlendirme hizmeti sunması mümkündür. ${ }^{[27]}$

\section{Elektif tedaviler}

Elektif tetkik ve tedavilerin pandemi dönemi sonrasına ertelenmesi planlanmalıdır. Tetkikler istenirken, tetkik sonucunun kısa dönemde tedaviyi değiştirip değiştirmeyeceği göz önünde tutularak karar verilmelidir. Tedavi kararı için gerekli olmadığına kanaat getirilen tetkiklerin pandemi dönemi sonrasına ertelenmesi, hem hasta ve yakınlarını, hem de sağlık personelini korumak açısından uygun olacaktır.

Epilepsi cerrahisi ve VNS gibi tedavilerin mümkünse bu dönemde uygulanmaması gerekir. Komorbid korona enfeksiyonlarının majör cerrahiler ve postop iyileşme dönemi üzerine negatif etkileri olduğu bildirilmektedir. Epilepsi cerrahisi gibi majör girişimler, bu dönemde yalnızca refrakter statuslar veya kısa sürede hayatı tehdit edebilecek intrakranyal kitleler gibi özel hastalarda uygulanmalıdır.

Akut girişim gerektiren olgular ile, uzun dönemde müdahale edilebilecek kronik olgular arasında bir gri zon söz konusudur. Bu gri zonda kısa sürede tetkikleri yapılmadığında veya tedavi edilmediğinde uzun vadede olumsuz sonuçlardan mustarip olabilecek progresif olgular yer almaktadır. Bu olgular söz konusu olduğunda, her vaka kendi özelinde ele alınmalı ve yarar zarar hesabı yapılarak hastanın ve yakınlarının da istekleri göz önünde tutularak karar verilmelidir.

\section{Hekimlerin Hekimler ve Halk Sağlığı İçin Yapabilecekleri}

Bilinmeyenlerle dolu bu pandemi döneminde, hekimlerin en önemli sorumluluklarından biri de bilgi sahibi olmak ve bilgiyi paylaşmaktır. Her gün yenileri eklenen bu bilimsel yayınlar okyanusunu mümkün olduğunca takip ederek bilgi birikimini güncel tutmak ve şartlar elveriyorsa da bu okyanusa katkıda bulunmak, dünyayı derinden sarsan bu pandemi döneminde hekimlerin kendileri, hastaları ve insanlık için yapabilecekleri en kıymetli şeylerdendir. İnsanlık tarihinin her bir anında bilimin ve bilginin ışığına ihtiyaç duyulmaktadır ancak bu ihtiyacın günümüzdeki kadar acil ve hayati olduğu dönemlerin sayısı bir elin parmakları kadardır.

\section{Hakem Değerlendirmesi}

Dış bağımsız.

\section{Çıkar Çatışması}

Yoktur.

\section{Yazarlık Katkıları}

Konsept: N.B.; Dizayn: N.B., A.D.E.; Veri Toplama veya İşleme: A.D.E., N.B., I.Y., S.A., E.A., K.A., S.K.V., S.N.Y.; Analiz ve Yorumlama: A.D.E., N.B., I.Y., S.A., E.A., K.A., S.K.V., S.N.Y.; Literatür Arama: N.B., A.D.E., I.Y.; Yazan: A.D.E., N.B., I.Y., S.A., E.A., K.A., S.K.V., S.N.Y.

\section{Kaynaklar}

1. Nath A. Neurologic complications of coronavirus infections. Neurology 2020;94(19):809-10. [CrossRef]

2. Acar T, Acıman Demirel E, Afşar N, Akçalı A, Akman Demir G, Alagöz AN, et al. Nörolojik Bakış Açısından COVID-19. Turk J Neurol 2020;26:56-106. [CrossRef]

3. Özdağ Acarli AN, Samanci B, Ekizoğlu E, Çakar A, Şirin NG, Gündüz T, et al. Coronavirus Disease 2019 (COVID-19) From the Point of View of Neurologists: Observation of Neurological Findings and Symptoms During the Combat Against a Pandemic. Noro Psikiyatr Ars 2020;57(2):154-9. [CrossRef]

4. Sorbello M, El-Boghdadly K, Di Giacinto I, Cataldo R, Esposito C, Falcetta S, et al. The Italian coronavirus disease 2019 outbreak: recommendations from clinical practice. Anaesthesia 2020;75(6):724-32. [CrossRef]

5. Guan WJ, Ni ZY, Hu Y, Liang WH, Ou CQ, He JX, et al. Clinical Characteristics of Coronavirus Disease 2019 in China. N Engl J Med 2020;382(18):1708-20. [CrossRef]

6. French JA, Brodie MJ, Caraballo R, Devinsky O, Ding D, Jehi L, et al. Keeping people with epilepsy safe during the COVID-19 pandemic. Neurology 2020;94(23):1032-7. [CrossRef]

7. Lu L, Xiong W, Liu D, Liu J, Yang D, Li N, et al. New onset acute symptomatic seizure and risk factors in coronavirus disease 2019: A retrospective multicenter study. Epilepsia 2020;61(6):e49-e53. [CrossRef] 
8. Mao L, Jin H, Wang M, Hu Y, Chen S, He Q, et al. Neurologic Manifestations of Hospitalized Patients With Coronavirus Disease 2019 in Wuhan, China. JAMA Neurol 2020;77(6):1-9. [CrossRef]

9. Aledo-Serrano Á, Mingorance A, Jiménez-Huete A, Toledano R, García-Morales I, Anciones C, et al. Genetic epilepsies and COVID-19 pandemic: Lessons from the caregiver perspective. Epilepsia. 2020;61(6):1312-4. [CrossRef]

10. Karimi N, Sharifi Razavi A, Rouhani N. Frequent Convulsive Seizures in an Adult Patient with COVID-19: A Case Report. Iran Red Crescent Med J 2020. [CrossRef]

11. Vollono C, Rollo E, Romozzi M, Frisullo G, Servidei S, Borghetti $A$, et al. Focal status epilepticus as unique clinical feature of COVID-19: A case report. Seizure 2020;78:109-12. [CrossRef]

12. Kuroda N. Epilepsy and COVID-19: Associations and important considerations. Epilepsy Behav 2020;108:107122. [CrossRef]

13. Kinney MO, Brigo F, Kaplan PW. Optimizing status epilepticus care during the COVID-19 pandemic. Epilepsy Behav 2020;109:107124. [CrossRef]

14. COVID-19 Drug Interactions. The Liverpool Drug Interaction Group (based at the University of Liverpool - UK) in collaboration with the University Hospital of Basel (Switzerland) and Radboud UMC (Netherlands) A. Available at: https://www. COVID19-druginteractions.org.

15. Pascarella G, Strumia A, Piliego C, Bruno F, Del Buono R, Costa F, et al. COVID-19 diagnosis and management: a comprehensive review. J Intern Med 2020;288(2):192-206. [CrossRef]

16. Malone DC, Hutchins DS, Haupert $H$, Hansten P, Duncan B, Van Bergen RC, et al. Assessment of potential drug-drug interactions with a prescription claims database. Am J Health Syst Pharm 2005;62(19):1983-91. [CrossRef]

17. Birbeck GL, French JA, Perucca E, Simpson DM, Fraimow $H$, George JM, et al; Quality Standards Subcommittee Of The American Academy Of Neurology; Ad Hoc Task Force Of The Commission On Therapeutic Strategies Of The International League Against Epilepsy. Antiepileptic drug selection for people with HIV/AIDS: evidence-based guidelines from the ILAE and AAN. Epilepsia 2012;53(1):207-14. [CrossRef]

18. Sheehan NL, Brouillette MJ, Delisle MS, Allan J. Possible interaction between lopinavir/ritonavir and valproic Acid exacerbates bipolar disorder. Ann Pharmacother 2006;40(1):147-50. [CrossRef]

19. American Clinical Neurophysiology Society. COVID-19 Resources for Clinical Neurophysiology. Available at: https://www.acns. org/practice/COVID-19-resources.

20. Rubiños C, Godoy DA. Electroencephalographic monitoring in the critically ill patient: What useful information can it contribute? Med Intensiva 2020;44(5):301-09. [CrossRef]

21. Herman ST, Abend NS, Bleck TP, Chapman KE, Drislane FW, Emerson RG, et al; Critical Care Continuous EEG Task Force of the American Clinical Neurophysiology Society. Consensus statement on continuous EEG in critically ill adults and children, part I: indications. J Clin Neurophysiol 2015;32(2):87-95. [CrossRef]

22. Türk Nöroloji Derneği. Tezer-Filik I. Pandemide EEG Laboratuvarında Çalışma Kılavuzu. Available at: https://www. noroloji.org.tr/haber/748/pandemi-surecinde-emg-ve-eeglaboratuvarlari-icin-oneriler.

23. Haines S, Caccamo A, Chan F, Galaso G, Catinchi A, Gupta PK. Practical Considerations When Performing Neurodiagnostic Studies on Patients with COVID-19 and Other Highly Virulent Diseases. Neurodiagn J 2020;60(2):78-95. [CrossRef]

24. Hao X, Zhou D, Li Z, Zeng G, Hao N, Li E, et al. Severe psychological distress among patients with epilepsy during the COVID-19 outbreak in southwest China. Epilepsia 2020;61(6):1166-73. [CrossRef]

25. Lai SL, Hsu MT, Chen SS. The impact of SARS on epilepsy: the experience of drug withdrawal in epileptic patients. Seizure 2005;14(8):557-61. [CrossRef]

26. American Academy of Neurology. Telemedicine and COVID-19 Webinar 2020. Available at: https://www.youtube.com/ watch? $\mathrm{v}=\mathrm{Pw}$-Jdy3-T9g.

27. Türkiye Klinikleri. Doktor Savunma-KOVID Süreçlerinde Hekimlerin Yasal Durumları 2020. Available at: https://www.turkiyeklinikleri.tv/program/doktor-savunma/9. 